\title{
Study on Relationship between Profile Characteristics of Bt Cotton Tenant Farmers with their Level of Knowledge on Recommended Package of Practices
}

\author{
Kantheti Vysali $^{1 *}$, P. Rambabu ${ }^{2}$ and Reshma J. Murugan ${ }^{1}$ \\ ${ }^{1}$ Department of Agricultural Extension, Agricultural College, Bapatla, India, \\ ${ }^{2}$ Director of Extension, Administrative office, ANGRAU, Lam, Guntur, India \\ *Corresponding author
}

\begin{abstract}
Keywords
Knowledge, Bt Cotton tenant farmers

Article Info

Accepted:

15 March 2019

Available Online:

10 April 2019 knowledge level of $B t$ cotton tenant farmers, correlation coefficients (r) was computed and the values were presented in Table 1. The relationship between the profile and knowledge level of $B t$ cotton tenant farmers were tested by null hypothesis and empirical hypothesis. The independent variables namely education, land taken for lease, training received, extension contact, social participation, annual income, credit acquisition and utilization, possession of soil health card, innovativeness, economic motivation, mass media exposure, risk orientation, market orientation showed a positive and significant relationship with knowledge of $B t$ cotton tenant farmers at 1 per cent level of significance. Whereas, age showed negative and non-significant relationship and farming experience showed positive and non-significant relationship with knowledge of $B t$ cotton tenant farmers. Multiple Linear Regression (MLR) analysis revealed that all the selected fifteen independent variables put together, explained about 78.80 per cent variation in the level of knowledge for $B t$ cotton tenant farmers. Remaining 21.20 per cent was due to the extraneous effect of the variables.
\end{abstract}

\section{A B S T R A C T}

The study was conducted in Andhra Pradesh state during 2017-18. A total of $120 \mathrm{Bt}$ cotton tenant farmers were selected randomly for the study. Data was collected with interview schedule. To study the nature of the relationship between the profile characteristics and

\section{Introduction}

In Andhra Pradesh cotton was cultivated in an area of 4.49 lakh hectares with a production of 13.10 lakh bales and productivity of 791 $\mathrm{Kg} / \mathrm{ha}$ in 2016-17 (Anonymous, 2016). Tenant farmers are those who cultivate crops by taking land on lease. Tenant farming is an agricultural production system in which land owners contribute their land and often takes care of operating capital and management; while tenant farmers contribute their labour along with at times varying amounts of capital and management. $B t$ cotton is genetically engineered cotton, which contains a gene taken from a soil bacterium (Bacillus thuringiensis) to produce toxins in the plants. The use of $B t$ cotton is a positive 
environmental protection because it makes possible the reduction of the insecticides load on the environment and reduced usage of such chemicals by farmers.

To achieve the higher level of production and productivity the inadequate level of knowledge of the recommended technology may be a big hindrance which also hampers the production potential of the cotton crops. So there is a need to help tenant farmers to realise the importance of production recommendations to achieve the objective of overcoming the gap between the potential yield and actual yield. So it is important to know the relation between profile characteristics and knowledge level of $B t$ cotton tenant farmers.

\section{Materials and Methods}

The investigation was carried out during the year 2017 in Guntur district of Andhra Pradesh by adopting ex-post facto research design. The state of Andhra Pradesh was selected purposively to get well acquainted with the regional language which would help to build a good rapport and also facilitates in depth study through personal observation. Guntur district was selected as it has the highest area under cotton cultivation.

Out of 57 mandals in Guntur district, three mandals were selected randomly after listing out the total number of mandals where tenant farmers were more in the cotton growing area. Three mandals, namely Prathipadu, Veldurthi, Karempudi were selected. After listing out the number of villages in each selected mandals, four villages were selected from each selected mandal randomly where tenant farmers were more with the cotton growing area. Ten tenant farmers were selected from each village by simple random sampling procedure Thus, making a total of 120 farmers. The data from the respondent farmers were collected with the help of schedules and interviews. The data collected was analysed and suitable interpretations were drawn. SPSS was used to analyse the data SPSS and presented in tables to make findings meaningful and easily understandable.

\section{Null hypothesis $\left(\mathbf{H}_{0}\right)$}

There will be no significant relationship between the selected profile characteristics and the knowledge level of the $B t$ cotton tenant farmers on recommended production technology.

\section{Empirical hypothesis $\left(\mathbf{H}_{1}\right)$}

There will be a significant relationship between the selected profile characteristics and the knowledge level of the $B t$ cotton tenant farmers on recommended production technology.

\section{Results and Discussion}

Correlation of profile characteristics with their knowledge level about recommended package of practices of $B t$ cotton tenant farmers

The results in the Table 1 revealed that out of fifteen independent variables studied namely education, land taken for lease, training received, extension contact, social participation, annual income, credit acquisition and utilization, possession of soil health card, innovativeness, economic motivation, mass media exposure, risk orientation, market orientation showed a positive and significant relationship with knowledge of $B t$ cotton tenant farmers at at 1 per cent level of significance. Hence, null hypothesis was rejected by accepting empirical hypothesis for the variables such as education, land taken for lease, training received, extension contact, social 
participation, annual income, credit acquisition and utilization, possession of soil health card, innovativeness, economic motivation, mass media exposure, risk orientation, market orientation.

Whereas, age showed negative and nonsignificant relationship and farming experience showed positive and nonsignificant relationship with knowledge of $B t$ cotton tenant farmers. Hence null hypothesis was accepted by rejecting empirical hypothesis for the variables such as age and farming experience.

\section{Age Vs knowledge}

The perusal of table 1 revealed that there was negative and non-significant relationship between age and knowledge level of $B t$ cotton tenant farmers with a computed coefficient of correlation value $\left(\mathrm{r}=-0.026^{\mathrm{NS}}\right)$. Hence null hypothesis was accepted by rejecting empirical hypothesis. This means as age increases, knowledge level decreases. This might be due to the reason that as age increases the recalling ability decreases and exposure to different technologies also decreases. The above finding was in line with the findings of Stina et al., (2013).

\section{Education Vs knowledge}

It is clear from the table 1 that the coefficient of correlation value $\left(\mathrm{r}=0.800^{* *}\right)$ between education and knowledge level of $B t$ cotton tenant farmers was positive and significantly related. Hence null hypothesis was rejected by accepting empirical hypothesis. This means higher the education levels, higher would be the extent of knowledge. This trend might be due to the fact that better education facilitates them to have more contact with extension agencies, better access to farm information such as magazines and have higher capabilities to grasp, analyze and interpret the information in better ways. The above finding was in conformity with the findings of Manjunath et al., (2012), Rajput et al., (2012).

\section{Land taken for lease Vs knowledge}

The results presented in the table 1 revealed that there was a positive and significant relationship between land taken for lease and knowledge level of $B t$ cotton tenant farmers with a computed $r$ value of $0.762^{* *}$. Hence null hypothesis was rejected by accepting empirical hypothesis.

This clearly implies that extent of knowledge increases with increase in land taken for lease. The reason might be due to the fact that a farmer with large holdings tends to acquire more information on cultivation practices to get higher profits. The above finding was in line with the finding of Rajput and Umesh (2016).

\section{Farming experience Vs knowledge}

The perusal of table 1 revealed that there was a positive and non significant relationship between farming experience and knowledge level of $B t$ cotton tenant farmers with a computed coefficient of correlation value $(r$ $\left.=0.111^{\mathrm{NS}}\right)$. Hence null hypothesis was accepted by rejecting empirical hypothesis. This trend might be due to the fact that knowledge might be present for both experienced and unexperienced $B t$ cotton tenant farmers based on their education, extension contact levels and their interaction with fellow farmers. The above finding was in line with the finding of Jaisridhar et al., (2013).

\section{Training received Vs knowledge}

It is clear from the table 1 that the coefficient of correlation value $\left(\mathrm{r}=0.424^{* *}\right)$ between training received and knowledge level of $B t$ 
cotton tenant farmers was positive and significantly related. Hence null hypothesis was rejected by accepting empirical hypothesis.

This means higher the trainings received higher would be the extent of knowledge. The possible reason might be due to the fact that farmers had attended training programmes which impart knowledge, skill and contacted the extension personnel to clarify the doubts and gain knowledge on production technologies of $B t$ cotton. The above finding was in conformity with the findings of Patel et al., (2011).

\section{Extension contact Vs knowledge}

The perusal of table 1 revealed that there was a positive and significant relationship between extension contact and knowledge level of $B t$ cotton tenant farmers with a computed coefficient of correlation value $\left(r=0.785^{* *}\right)$. Hence null hypothesis was rejected by accepting empirical hypothesis. This clearly implies that extent of knowledge increases with increase in extension contact.

This can be inferred that $B t$ cotton tenant farmers approach extension personnel like MPEOs, AEOs when they need information regarding agricultural practices on production technologies in agriculture in their area. This extension contact enables the farmer to different kinds of information, thus resulting in the increase of knowledge. This finding was in agreement with the findings of Manjunath et al., (2012) and Rajput et al., (2012).

\section{Social participation Vs knowledge}

The results presented in the table 1 revealed that there was a positive and significant relationship between social participation and knowledge level of $B t$ cotton tenant farmers with computed $r$ value of $0.403^{* *}$. Hence null hypothesis was rejected by accepting empirical hypothesis. This clearly implies that extent of knowledge increases with the increase in social participation. Farmers who actively participate in social organizations come close to different types of people, exchange one's views and experiences, discuss problems and seek solutions which result in the gain of more and more knowledge. The above finding was in line with the finding of Reddy et al., (2014).

\section{Annual income Vs knowledge}

The perusal of table 1 revealed that there was a positive and significant relationship between annual income and knowledge level of $B t$ cotton tenant farmers with a computed coefficient of correlation value $\left(r=0.732^{* *}\right)$. Hence null hypothesis was rejected by accepting empirical hypothesis. This clearly implies that extent of knowledge increases with an increase in annual income. This trend might be due to the fact that as the farmer gets more income he will be more cosmopolite in nature and will have more contacts with extension personnel and gets more farm information. The above finding was in line with the finding of Rao (2011).

\section{Credit acquisition and utilization Vs Knowledge}

The perusal of table 1 revealed that there was a positive and significant relationship between credit acquisition and utilization and knowledge level of $B t$ cotton tenant farmers with a computed coefficient of correlation value $\left(\mathrm{r}=0.770^{* * *}\right)$. Hence null hypothesis was rejected by accepting empirical hypothesis.

This implies that as the credit acquisition and utilization increases, knowledge also increases significantly. Capital is one of the most important initiating inputs to a farmer 
for cultivation. A farmer with more credit may approaches extension personnel more to avoid risks in cultivation and gain information regarding scientific cultivation of $B t$ cotton in order to avoid risks and also to decrease cost of cultivation. The above finding is away from the other findings.

\section{Possession of soil health card Vs knowledge}

The results presented in the table 1 revealed that there was a positive and significant relationship between possession of soil health card and knowledge level of $B t$ cotton tenant farmers with computed $r$ value of $0.543^{* *}$ Hence null hypothesis was rejected by accepting empirical hypothesis. This clearly implies that extent of knowledge increases with increase in possession of soil health card. Soil health card provides a lot of information regarding nutrient content in their soil without which one cannot estimate the nutrient content of soil. So, it provides knowledge regarding the quantities of fertilizers to be applied to their soil.

\section{Innovativeness Vs knowledge}

The perusal of table 1 revealed that there was a positive and significant relationship between innovativeness and knowledge level of $B t$ cotton tenant farmers with a computed coefficient of correlation value $\left(r=0.780^{* *}\right)$. Hence null hypothesis was rejected by accepting empirical hypothesis.

This implies that as the innovativeness increases, knowledge also increases significantly. This trend might be due to the fact that a farmer with higher innovativeness had the higher desire to seek information from various reliable sources such as farm magazines, extension personnel and scientists resulting in gain of knowledge about production technologies. This finding was in agreement with the findings of Reddy et al., (2014).

\section{Economic motivation Vs knowledge}

The perusal of table 1 revealed that there was a positive and significant relationship between economic motivation and knowledge level of $B t$ cotton tenant farmers with a computed coefficient of correlation value $\left(r=0.794^{* *}\right)$. Hence null hypothesis was rejected by accepting empirical hypothesis.

This implies that as the economic motivation increases, knowledge also increases significantly. As the economic motivation increases, the farmers always try to get maximum yields to improve their economic level by acquiring knowledge from various sources about $B t$ cotton cultivation practices. This finding was in agreement with the findings of Sakthi (2008).

\section{Mass media exposure Vs knowledge}

It is clear from the table 1 that the coefficient of correlation value $\left(\mathrm{r}=0.740^{* *}\right)$ between mass media exposure and knowledge level of $B t$ cotton tenant farmers was positive and significantly related. Hence null hypothesis was rejected by accepting empirical hypothesis. This means the higher the mass media exposure, higher would be the extent of knowledge. This is because of the reason that the farmers who keep in touch with the mass media such as television, newspapers, mobiles, and the internet will have greater exposure to farm information which helps to improve the knowledge level of the $B t$ cotton tenant farmers because mass media is a powerful source of spreading information. The above finding was in conformity with the findings of Manjunath et al., (2012).

\section{Risk orientation Vs knowledge}

The results presented in the table 1 revealed that there was a positive and significant relationship between risk orientation and knowledge level of $B t$ cotton tenant farmers 
with computed $\mathrm{r}$ value of $0.793^{* *}$. Hence null hypothesis was rejected by accepting empirical hypothesis. This clearly implies that extent of knowledge increases with an increase in risk orientation.

This is because of the reason that the farmer who is willing to take calculated risks during constraint situation will gain better results. Those risk taking individuals will go out all the way to get the information from different sources in order to gain more knowledge. This finding was in agreement with the findings of Rajput et al., (2012).

\section{Market orientation Vs knowledge}

It is clear from the table 1 that the coefficient of correlation value $\left(\mathrm{r}=0.782^{* *}\right)$ between market orientation and knowledge level of $B t$ cotton tenant farmers was positive and significantly related. Hence null hypothesis was rejected by accepting empirical hypothesis. This clearly implies that extent of knowledge increases with an increase in market orientation. This might be due to the fact that the farmers who pay attention to market information on prices in order to get high income, they try to improve their knowledge. The above finding was in conformity with the findings of Sriramana (2014).

Multiple linear regression analysis of profile characteristics of $B t$ cotton tenant farmers with their extent of knowledge level

From the above table no 2. The MLR equation can be fitted as follows:

$$
\begin{aligned}
& \mathrm{Y}=2.498+0.091 * \mathrm{x}_{1}+1.107 * \mathrm{x}_{2}+0.495 \mathrm{x}_{3}- \\
& 0.285^{*} \mathrm{x}_{4}-0.048 \mathrm{x}_{5}+0.234 \mathrm{x}_{6}-0.268 \mathrm{x}_{7}+ \\
& 0.000 \mathrm{x}_{8}+0.941 \mathrm{x}_{9}+0.591 \mathrm{x}_{10}+0.042 \mathrm{x}_{11}+ \\
& 0.256 \mathrm{x}_{12}-0.340 \mathrm{x}_{13}+0.012 \mathrm{x}_{14}+0.890 \mathrm{x}_{15}
\end{aligned}
$$

Table.1 Correlation coefficient values of profile characteristics with their knowledge level of Bt cotton tenant farmers

\begin{tabular}{|c|l|c|}
\hline \multicolumn{1}{|c|}{ Profile Characteristics } & 'n=120) \\
\hline S. No. & \multicolumn{1}{|c|}{$\mathrm{r}^{\prime}$ value } \\
\hline 1. & Age & $-0.026^{\mathrm{NS}}$ \\
\hline 2. & Education & $0.800^{* *}$ \\
\hline 3. & Land taken for lease & $0.762^{* *}$ \\
\hline 4. & Farming experience & $0.111 \mathrm{NS}$ \\
\hline 5. & Training received & $0.424^{* *}$ \\
\hline 6. & Extension contact & $0.785^{* *}$ \\
\hline 7. & Social participation & $0.403^{* *}$ \\
\hline 8. & Annual income & $0.732^{* *}$ \\
\hline 9. & Credit acquisition and utilization & $0.770^{* *}$ \\
\hline 10. & Possession of soil health card & $0.543^{* *}$ \\
\hline 11. & Innovativeness & $0.780^{* *}$ \\
\hline 12. & Economic motivation & $0.794^{* *}$ \\
\hline 13. & Mass media exposure & $0.740^{* *}$ \\
\hline 14. & Risk orientation & $0.793^{* *}$ \\
\hline 15. & Market orientation & $0.782^{* *}$ \\
\hline \multicolumn{2}{|c|}{ NS $=$ Non-significant Significant at 0.01 level of probability } \\
\hline
\end{tabular}


Table.2 Multiple linear regression analysis of profile characteristics of Bt cotton tenant farmers with their extent of knowledge level

\begin{tabular}{|c|c|c|c|c|}
\hline & & & \multicolumn{2}{|c|}{$(n=120)$} \\
\hline S. No. & Profile Characteristics & $\begin{array}{l}\text { b (Regression } \\
\text { co-efficient) }\end{array}$ & $\begin{array}{l}\text { Standard } \\
\text { error }\end{array}$ & 't' value \\
\hline 1. & Age & 0.091 & 0.032 & $2.884^{*}$ \\
\hline 2. & Education & 1.107 & 0.481 & $2.300^{*}$ \\
\hline 3. & Land taken for lease & 0.495 & 1.415 & $0.350^{\mathrm{NS}}$ \\
\hline 4. & Farming experience & -0.285 & 0.134 & $-2.123 *$ \\
\hline 5. & Training received & -0.048 & 0.239 & $-0.200^{\mathrm{NS}}$ \\
\hline 6. & Extension contact & 0.234 & 0.550 & $0.426^{\mathrm{NS}}$ \\
\hline 7. & Social participation & -0.268 & 0.279 & $-0.962^{\mathrm{NS}}$ \\
\hline 8. & Annual income & 0.000 & 0.000 & $0.791^{\mathrm{NS}}$ \\
\hline 9. & Credit acquisition and utilization & 0.941 & 0.940 & $1.000^{\mathrm{NS}}$ \\
\hline 10. & Possession of soil health card & 0.591 & 2.141 & $0.276^{\mathrm{NS}}$ \\
\hline 11. & Innovativeness & 0.042 & 0.116 & $0.365^{\mathrm{NS}}$ \\
\hline 12. & Economic motivation & 0.256 & 0.359 & $0.713^{\mathrm{NS}}$ \\
\hline 13. & Mass media exposure & -0.340 & 0.643 & $-0.529^{\mathrm{NS}}$ \\
\hline 14. & Risk orientation & 0.012 & 0.512 & $0.023^{\mathrm{NS}}$ \\
\hline 15. & Market orientation & 0.890 & 0.655 & $1.359^{\mathrm{NS}}$ \\
\hline $\begin{array}{l}\mathrm{a}= \\
\mathrm{R}^{2}\end{array}$ & $\begin{array}{l}2.498 \\
0.788\end{array}$ & $\begin{array}{l}\text { nt at } 0.05 \text { level o } \\
\text { n significant }\end{array}$ & bability & \\
\hline
\end{tabular}

Table 2 revealed that the coefficient of determination " $\mathrm{R}$ " " value of 0.788 indicated that all the selected fifteen independent variables put together, explained about 78.80 per cent variation in the level of knowledge for $B t$ cotton tenant farmers.

Remaining 21.20 per cent was due to the extraneous effect of the variables. Hence, it could be stated that the variables selected to a large extent explained the variation in level of knowledge of $B t$ cotton tenant farmers.

The regression coefficient given in the table 2 further revealed that the profile characteristics, namely age, education were found to be positively significant and farming experience as negatively significant at 0.05 level of probability.

Remaining variables viz., land taken for lease, training received, extension contact, social participation, annual income, credit acquisition and utilization, possession of soil health card, innovativeness, economic motivation, mass media exposure, risk orientation, market orientation were non significant in this analysis.

A unit of change in age influences positively 0.091 times, education influences positively 1.107 times, farming experience influences negatively 0.285 times in knowledge.

This might be due to the fact that the most of the $B t$ cotton tenant farmers were middle aged who were having better knowledge than the old aged people because middle aged people are more enthusiastic, energetic, higher exposure to mass media for different sources of farm information, higher extension contact and high recalling ability. Education played a greater role in acquiring and understanding the information that widened the thinking 
horizon and made the farmer more changed and knowledgeable.

\section{References}

Anonymous, 2016. All India Co-ordinated Research Project on Cotton Annual Report: 2016. http://www.aiccip. cicr.org.in/CD_16_17/3_PC_Report.pdf

Jaisridhar, P., Ravichandran, $\mathrm{V}$ and Sangeetha, S. 2013. Behavioural correlates of commercial maize growers. Journal of Extension Education. 25(1): 4980-4981.

Manjunath, V.B., Hanchinal, S.N., Maraddi, G.N., Binkadakatti, J.S and Shambulingappa, B.G. 2012. Analysis of extent of adoption of $B t$ cotton recommended production practices followed by the farmers. Asian Science. 7 (1): 5-8.

Patel, J.B., Patel, A.C and Sharma, T.D. 2011. Factors influencing knowledge level of cotton growers about integrated pest management technology. Karnataka Journal of Agriculture Sciences. 24 (4): 464-466.

Rajput, H.D and Umesh, C.R. 2016. Knowledge and adoption of $B t$ cotton cultivation practices. Indian Journal of Extension Education. 52 (1\&2): 121123.

Rajput, H.D., Chinchmalatpure, U.R and
Girase, C.P. 2012. Correlates of knowledge of $B t$ cotton cultivation practices. International Journal of Farm Sciences. 2 (1): 111-115.

Rao, B.M. 2011. An analysis study on $B t$ cotton in Andhra Pradesh. Ph. D. (Ag.) Thesis. Acharya N.G. Ranga Agricultural University, Hyderabad, India.

Reddy, P.N., Lakshmi, T and Prasad, S.V. 2014. Correlation analysis between profile characteristics of cotton farmers with their knowledge on health hazards of pesticides usage in Kurnool district of Andhra Pradesh. International Journal of Scientific Research. 3 (6): 12-13.

Sakthi, B. 2008. knowledge and adoption of $B t$ cotton growers in Peramballur district. M. Sc. (Ag.) Thesis. Tamil Nadu Aricultural University, Coimbatore, India.

Sriramana, V. 2014. Knowledge and extent of adoption of cashew growers in Srikakulam district of Andhra Pradesh. M. Sc. (Ag.) Thesis. Acharya N.G. Ranga Agricultural University, Guntur, India.

Stina, Kh., Devi, U.S., Ram, D and Singh, M.K. 2013. Awareness of jobcard holders under NREGA scheme. Journal of communication Studies. 31 (1): 159163.

\section{How to cite this article:}

Kantheti Vysali, P. Rambabu and Reshma J. Murugan. 2019. Study on Relationship between Profile Characteristics of Bt Cotton Tenant Farmers with their Level of Knowledge on Recommended Package of Practices. Int.J.Curr.Microbiol.App.Sci. 8(04): 1947-1954. doi: https://doi.org/10.20546/ijcmas.2019.804.228 